Приступа Л. А. ${ }^{[1 ; 0 R C I D ~ I D: ~ 0000-0002-5088-0654], ~}$ к.е.н.,

Коваль В. В. [2; ORCID ID: 0000-0003-2562-4373], д.е.н., професор,

Коваленко-Марченкова Є. В. [3; ORCID ID: 0000-0001-7350-7740], к.е.н., доцент

\author{
${ }^{1}$ Хмельницький національний університет, м. Хмельницький, Україна \\ ${ }^{2}$ Одеський торговельно-економічний інститут Київського національного торговельно- \\ економічного університету, м. Одеса, Україна \\ ${ }^{3}$ Дніпропетровський державний університет внутрішніх справ, м. Дніпро, Україна
}

\title{
УПРАВЛІННЯ РОЗВИТКОМ НАЦІОНАЛЬНОГО БАНКІВСЬКОГО СЕКТОРУ НА ОСНОВІ ЗАБЕЗПЕЧЕННЯ ФІНАНСОВОЇ БЕЗПЕКИ БАНКІВСЬКИХ УСТАНОВ
}

У статті розкрито сучасне розуміння сутності поняття «фінансова безпека банку» на основі аналітичного дослідження існуючих підходів до трактування змісту фінансова безпека суб'єкта господарювання та трактування категорії фінансової безпеки банку. Зазначено умови розвитку, актуальні явища та фактори, що можуть спричиняти внутрішні загрози національному банківському сектору загалом та його установам. Розкрито інструменти протидії наслідкам загроз у банківському секторі, ефективно застосовані на рівні регулятора, та, на основі аналітичного оцінювання стану й тенденцій ризиків банківського сектору за період 2015-2020 років, запропоновано етапну послідовність процесу ризикменеджменту та виділено пріоритетні складові підвищення рівня фінансової безпеки вітчизняних банківських установ.

Ключові слова: банківський сектор; банк; фінансова безпека; управління; загрози; ризики.

Постановка проблеми. Реалії функціонування та розвитку національної економіки на сучасному етапі супроводжуються фінансовою нестабільністю конкурентного середовища, проявами кризових явищ і посиленням впливу існуючих та нових ризиків й загроз. Негативний вплив зазначених факторів відчувають на собі всі економічні суб'єкти, проте банківський сектор як основний елемент фінансової підтримки та забезпечення сталого функціонування реального сектору економіки повинен бути першочергово орієнтований на забезпечення фінансової безпеки діючих інституцій.

Аналіз досліджень і публікацій. Базові концептуальні засади 
розвитку національного банківського сектору на основі забезпечення фінансової безпеки відображені у працях багатьох українських вчених: О.М.Джужі [1], О.Барановського [2], А. Єпіфанова [3], Р. Вовченко [4], І. Губарєвої [5], Н. Зачосової [6] та інших. Водночас, враховуючи значний динамізм вітчизняного економічного середовища, посилення впливу глобалізаційних процесів на функціонування вітчизняної економіки, розвиток та поширення несприятливих обставин та нарощення сукупності ризиків щодо діяльності банківських контрагентів вітчизняні економісти продовжують дослідження питань даної площини щодо пошуку та можливостей впровадження нових концепцій та підходів управлінської роботи як на рівні банківського сектору, так і безпосередньо банківської установи [7-8].

Віддаючи належне науковому доробку вчених-економістів, слід зазначити, що проблеми забезпечення фінансової безпеки вітчизняних банків, як складової механізму розвитку банківського сектору України, потребують подальших системних досліджень, безпосередньо щодо визначення актуальних та розробки дієвих концепцій, механізмів, методів та технологій управлінського впливу 3 урахуванням особливостей як вітчизняної економіки загалом, так і банківського сектору зокрема.

Постановка завдання. Метою статті $\epsilon$ обґрунтування теоретичних та організаційно-економічних домінант механізмів розвитку національного банківського сектору на основі забезпечення фінансової безпеки банківських установ в умовах дії факторів внутрішнього та зовнішнього середовища функціонування.

Основні результати дослідження. В сучасних дослідженнях тлумачення фінансової безпеки як рівня фінансового стану неповною мірою формулює сутнісну і методологічну складову цієї дефініції, що надто звужує найбільш розширене трактування.

Відповідно до розмаїття поглядів дослідників на проблему фінансової безпеки суб'єктів господарювання не менш різноманітними є трактування категорії фінансової безпеки банку через сутність стабільності й стійкості фінансового стану банківської установи. Також важливим $\epsilon$ ступінь ефективності фінансовоекономічної діяльності, рівень контролю за зовнішніми і внутрішніми ризиками, рівень достатності капіталу та ступінь захищеності інтересів акціонерів [9].

Зважаючи на це, доцільним є розгляд сутності, видів на наслідків загроз внутрішнього та зовнішнього середовища функціонування вітчизняних банківських установ. Під загрозою 
загалом та фінансовій безпеці банку безпосередньо слід розуміти негативний вплив з боку вхідних параметрів, які супроводжують зміну вихідної інформації системи. Перебуваючи у стані невизначеності, можливої зміни як внутрішніх, так і зовнішніх чинників діяльності, менеджмент банку приймає ризикові рішення в умовах гострої конкуренції, вживаючи заходів запобігання прогнозованих небезпек і нейтралізації наявних загроз (таблиця), забезпечуючи тим самим ефективну систему ідентифікації та досягнення стратегічних цілей розвитку.

Таблиця

Загрози фінансовій безпеці банку та їх наслідки

\begin{tabular}{|c|c|}
\hline Вид загрози & Наслідки \\
\hline \multicolumn{2}{|r|}{ ВНУТРІШНІ ЗАГРОЗИ } \\
\hline $\begin{array}{l}\text { Неефективна кредитна } \\
\text { політика банку }\end{array}$ & $\begin{array}{l}\text { - зниження якості кредитного портфеля; } \\
\text { - підвищення суми обов'язкових кредитів; } \\
\text { - зниження } \\
\text { кредитних пропозицій }\end{array}$ \\
\hline $\begin{array}{l}\text { Низька якість управління } \\
\text { активами та пасивами } \\
\text { банку }\end{array}$ & $\begin{array}{l}\text { - зниження рівня ліквідності; } \\
\text { - підвищення рівня ризикових активів; } \\
\text { - незбалансованість активів за строками }\end{array}$ \\
\hline $\begin{array}{l}\text { Некомпетентність вищого } \\
\text { керівництва }\end{array}$ & $\begin{array}{l}\text { - низький рівень стратегічного планування; } \\
\text { - приймання неефективних управлінських } \\
\text { рішень }\end{array}$ \\
\hline $\begin{array}{l}\text { Некомпетентність } \\
\text { персоналу банку }\end{array}$ & $\begin{array}{l}\text { - розголошення конфіденційної інформації; } \\
\text { - послаблення конкурентних позицій }\end{array}$ \\
\hline \multicolumn{2}{|r|}{ ЗОВНІШНІ ЗАГРОЗИ } \\
\hline $\begin{array}{l}\text { Недосконалість } \\
\text { банківського } \\
\text { законодавства }\end{array}$ & $\begin{array}{l}\text { - зміна умов ліцензування та мінливість } \\
\text { нормативно-правових актів; } \\
\text { - завищенні міжнародні норми; } \\
\text { - залежність від політичних факторів }\end{array}$ \\
\hline $\begin{array}{l}\text { Низький рівень } \\
\text { інвестиційної активності }\end{array}$ & $\begin{array}{l}\text { - відсутність інвестиційно привабливих } \\
\text { проектів на внутрішньому ринку; } \\
\text { - неспроможність банку залучати інвестиції } \\
\text { через неефективну діяльність }\end{array}$ \\
\hline $\begin{array}{l}\text { Недобросовісна } \\
\text { конкуренція }\end{array}$ & $\begin{array}{l}\text { - різке зниження депозитних кредитних } \\
\text { ставок з боку нестабільних установ; } \\
\text { - компрометація з боку партнерів; } \\
\text { - штучне банкрутство підприємств }\end{array}$ \\
\hline $\begin{array}{l}\text { Високий рівень недовіри } \\
\text { до банків }\end{array}$ & $\begin{array}{l}\text { - недовіра з боку вкладників та кредиторів; } \\
\text { - банкрутство банків; } \\
\text { - погіршення репутації банків }\end{array}$ \\
\hline
\end{tabular}

Джерело: узагальнено на основі [3-5; 16]

Важливе місце у безпекознавстві відводиться визначенню причинно-наслідкового зв'язку процесу стимулювання та 
виникнення загроз щодо того чи іншого явища або процесу, тому потребують визначення співвідношення понять «загрози», «виклики» і «небезпеки».

Зокрема «виклик» визначають як певну сукупність обставин, що не обов'язково мають конкретно характер загрози, але передбачають обов'язкове реагування на їх виникнення; початкову стадію формування загрози; певну сукупність явищ і процесів, що в конкретний момент не впливають на рівень забезпечення економічної безпеки, однак за відсутності реакції на їх виникнення забезпечення високого рівня економічної безпеки у наступні періоди $€$ вельми проблематичним. Таким чином, можна стверджувати, що категорія «виклик» $€$ первинною складовою взаємозалежності «небезпека - безпека».

Небезпека має розглядатися як об'єктивно існуюча можливість негативного впливу, результатом якого буде зниження рівня економічної безпеки, а іï визначальною характеристикою $\epsilon$ ї̈ потенційний характер, тобто при настанні загрози небезпека зникає як така.

В ракурсі цього, загроза $€$ найбільш конкретною і безпосередньою формою небезпеки в економічній сфері, сукупність негативних умов та чинників, що формують можливість зниження рівня економічної безпеки.

В загальному схему розвитку негативного впливу на об'єкт від ризику до загрози відображено на рисунку 1.
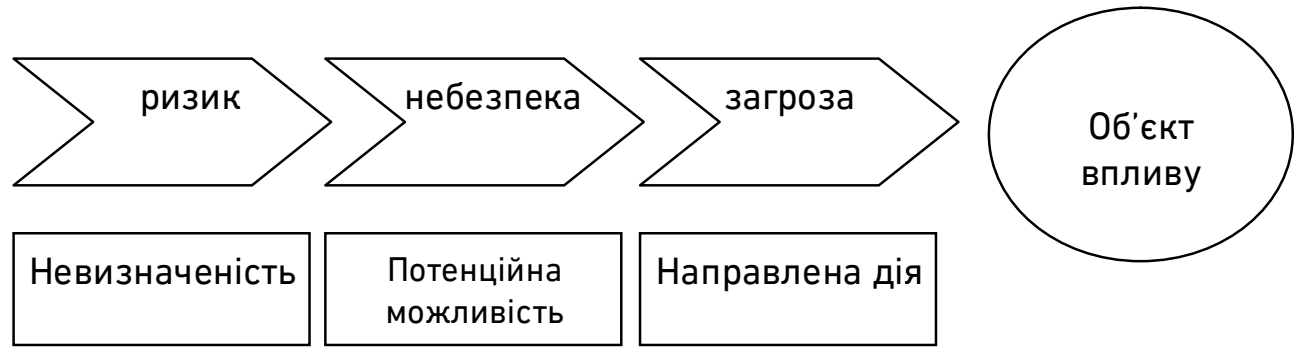

Рис. 1. Причинно-наслідковий зв'язок виникнення та розвитку ризику, небезпеки і загрози (складено на основі [16, С. 51])

Під системою забезпечення безпеки банку доцільно розуміти сукупність об'єктів, суб'єктів, принципів, функцій, методів оцінювання та механізму зміцнення безпеки банку, що підпорядковані спільній меті та поставленим завданням попередження загроз та протидії їм, зміцнення позицій банку як на внутрішньому ринку, так й на зовнішньому, підвищення ефективності його діяльності.

Суб'єктами системи забезпечення фінансової безпеки 
банківської установи слід вважати окремих посадових осіб, відповідні служби банку та його керівників, Національний банк України, банківську систему, державні органи нагляду та контролю, які вживають заходів щодо зміцнення безпеки банку та підвищення ефективності його діяльності.

Система забезпечення безпеки банку повинна посідати одне 3 ключових місць у системі управління банком для вчасного виявлення ймовірних ризиків та загроз, попередження їх появи та ефективної нейтралізації, що сприятиме оптимізації фінансового управління банком та підвищенню ефективності його діяльності. При цьому, слід враховувати, що система забезпечення безпеки банку взаємодіє із зовнішнім середовищем, впливаючи на нього та зазнаючи зворотного впливу. Ефективне функціонування системи забезпечення фінансової безпеки банку передбачає проходження певних етапів, серед яких слід виділити:

- постійне збирання даних і діагностику фінансового стану банку, можливих ризиків та загроз, рівня фінансової безпеки;

- розроблення і застосування системи необхідних превентивних та антикризових явищ;

- контролювання за виконанням прийнятих рішень;

- оцінювання ефективності роботи системи;

- вдосконалення системи забезпечення фінансової безпеки банку.

Таким чином, функціонування системи забезпечення фінансової безпеки банку повинно базуватись на певному алгоритмі управлінських дій, що відрізнятиметься в залежності від встановленого рівня фінансової безпеки, сприяючи попередженню виникнення загрозливих ситуацій та недопущенню появи їх наслідків.

Проте, відповідна система функціонуватиме лише в об'єктивних умовах внутрішнього та зовнішнього середовища, а за навмисного втручання чи фальшування інформації вона може зазнавати дестабілізуючого впливу.

Фінансова безпека вітчизняних банківських установ залежить від умов функціонування національного фінансового ринку та безпосередньо банківського сектору, що останніми роками відбувалось в складному операційному середовищі та визначалось наслідками політичної та економічної кризи, анексією Автономної Республіки Крим та військовими діями на Сході країни, а також сукупністю факторів мікро-, мезо-, макро- і мегарівня.

Сучасний стан та тенденції розвитку вітчизняного банківського сектору й забезпечення достатнього рівня фінансової безпеки 
діючих банківських установ передусім визначаються здатністю та можливостями подолання реалізації глобального ризику пандемії, що як і в інших секторах економіки спричинив коронакризу. Потрібно зауважити, що проведена у 2015 році робота регулятора з очищення та підвищення стійкості банківського сектору, убезпечила національну економіку від додаткового фактору економічної нестабільності, при цьому банківські установи продовжували роботу у штатному режимі, продовжуючи видавати кредити та шукаючи можливості активної співпраці з клієнтською базою в інтерактивному режимі.

Національним банком України, враховуючи позитивний досвід зарубіжних країн, було задіяно широкий спектр регулюючих інструментів для пом'якшення наслідків кризи на пікових періодах.

Аналізуючи карту наявних ризиків банківського сектору України (рис. 2), спостерігаємо що незмінністю значень вирізняються ризик ліквідності, валютний ризик та ризик прибутковості. Крім цього, більш впливові ризики - кредитний ризик (відображає перспективи зміни рівня непрацюючих кредитів у портфелях банків та необхідність додаткового формування резервів під такі кредити) та ризик достатності капіталу (оцінює можливості банків забезпечувати достатній рівень капіталу) за даними грудня 2020 року вдалось зменшити у порівнянні з червневими показниками. Оберненою була тенденція щодо рівня юридичного ризику, що визначається на кінець року на максимальному поміж інших показників рівні - 8 .

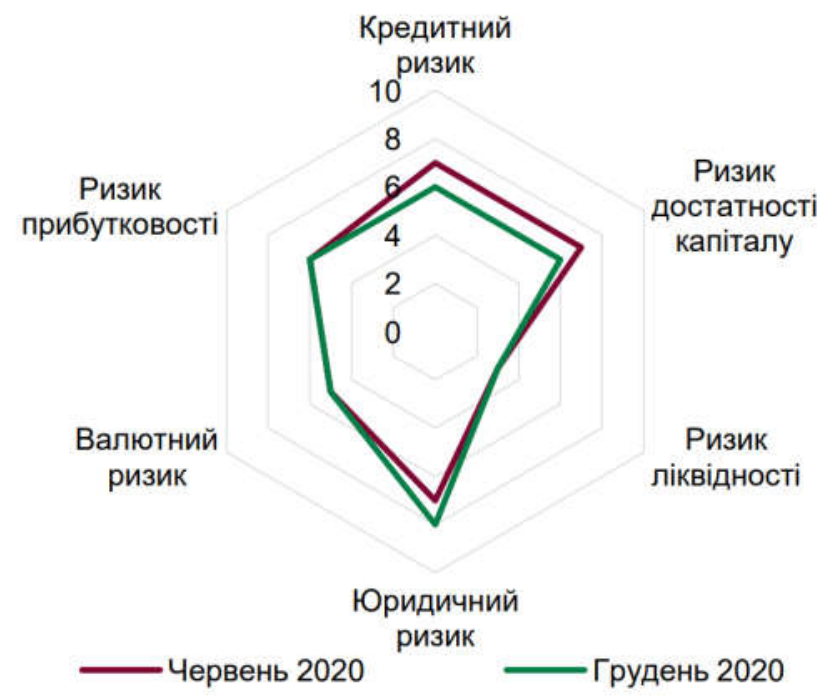

Рис. 2. Карта ризиків банківського сектору [17]

Оцінюючи вплив відповідних ризиків вітчизняного банківського сектору протягом 2015-2020 років (рис. 3), спостерігаємо, що 
найбільш критичні значення були характерні для показників 2015 року, де всі рівні ризиків знаходились у діапазоні більше 5, а особливо проблемними були ризик достатності капіталу та ризик прибутковості, кредитний ризик взагалі знаходився на критично високому рівні. Поступове вирівнювання ситуації та покращення показників оцінки ризиковості банківського сектору відбулось у 2017 році із закріпленням відповідних тенденцій у 2018 та 2019 роках. Попри це, за даними 2020 року спостерігається погіршення оцінюваних рівнів показників ризиковості щодо кредитного ризику, ризику достатності капіталу та ризику прибутковості. До загальних позитивних зрушень 2020 року потрібно віднести зменшення ризику ліквідності та загальне зниження рівня юридичного ризику у порівнянні з критичними рівнями даного показника у 2017-2018 роках, що було найвідчутнішим фактором негативного впливу протягом зазначеного періоду.

\begin{tabular}{|c|c|c|c|c|c|c|}
\hline Ризики & 12.15 & 2016 & 2017 & 2018 & 2019 & 06.2009 .20 \\
\hline Кредитний & & & & & & \\
\hline \multicolumn{7}{|l|}{ Достатн. капіталу } \\
\hline \multicolumn{7}{|l|}{ Ліквідності } \\
\hline \multicolumn{7}{|l|}{ Юридичний } \\
\hline \multicolumn{7}{|l|}{ Валютний } \\
\hline \multicolumn{7}{|l|}{ Прибутковості } \\
\hline Середнє знач. & & & & & & \\
\hline
\end{tabular}

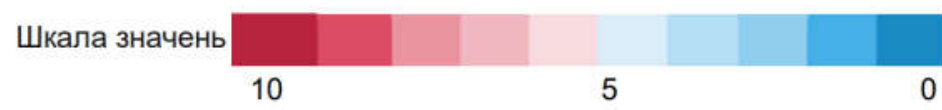

Рис. 3. Теплова карта ризиків банківського сектору [17]

Погіршення фінансового стану вітчизняних банків, за даними НБУ [22], засвідчилось у зниженні на 25\% прибутку банківського сектору за 10 місяців 2020 року. Більша частина банків зберегли рентабельність капіталу понад 15\%. Чисті процентні доходи зростали завдяки збереженню високого процентного спреду - протягом року ставки за активами та зобов'язаннями знижувалися паралельно. Водночас звуження спреду в середньостроковій перспективі неминуче, що $€$ ключовим ризиком для прибутковості банків у наступні роки.

Висновки. Отже, в загальному розпізнавання загроз i оцінювання ризиків для забезпечення сталого розвитку та високого рівня фінансової безпеки банківської установи досягається за рахунок реалізації функцій, застосування методів, інструментів, управлінського впливу на вірно ідентифіковані об'єкти та цілі. В даному контексті процес ризик-менеджменту у вітчизняній банківській установі повинен передбачати наступні етапи: 
встановлення контексту ризиків; моніторинг ризиків (проведення аналітичних спостережень на постійній основі щодо лімітів та розмірів ризиків, і ризиків, які не передбачають кількісного оцінювання). В свою чергу ефективність ризик-менеджменту визначатиметься системністю роботи, адекватністю аналітичного інструментарію, оптимізацією контрольних заходів та процедур й своєчасністю реагування з боку банків та регулятора, що актуалізує подальшу розробку домінант методичного забезпечення.

1. Економічна безпека / за ред. О. М. Джужі. К.: Алерта, 2010. 368 с. 2. Барановський О. Безпека банківської сфери. Вісник НБУ. 2014. № 6. С. 20-27. 3. Єпіфанов А. О. Фінансова безпека підприємств і банківських установ : монографія. Суми : ДВНЗ «УАБС НБУ», 2009. 295 с. 4. Вовченко Р. С. Фінансова безпека банківського сектору економіки України : дис. ... канд. екон. наук : 08.00.08. К., 2016. 237 с. 5. Губарєва І. 0. Забезпечення управління економічною безпекою банку : монографія. Харків: Інжек, 2013. 309 с. 6. Зачосова Н. В. Формування системи економічної безпеки фінансових установ : монографія. Черкаси: ПП Чабаненко Ю.А, 2016. 375 с. 7. Барилюк М.-М.Р. Аналіз чинників впливу на процес забезпечення фінансової безпеки комерційного банку. Фінансовий простір. 2017. № 1. С.8-17. 8. Лісняк А. Є. Еволюція і класифікації показників оцінювання фінансової безпеки банків. Фінансовий простір. 2018. № 3. С. 60-68. 9. Шевців Л. Ю. Шляхи підвищення фінансової безпеки банків України в умовах глобалізацій них процесів. Бізнес-інформ. 2020. № 9. С. 254-262. 10. Baranovskyi A. Integral assessment of the financial security of commercial banks. Scientific Light. 2017. № 7. P. 34-45. 11. Prystupa L. Conceptual framework of financial security management of domestic banks in the current economic conditions. Сучасні виклики сталого розвитку бізнесу : матеріали Міжнародної наукової конференції (56 листопада 2020 р., м. Житомир). Житомир: ДУЖП, 2020. С. 167-171. 12. Prystupa L. Assessment of bank's financial security levels based on a comprehensive index using information technology. Machine Learning for Prediction of Emergent Economy Dynamics. 2020. Vol. 2713, Рp. 23. 13. Перекрестова Л. В. Внешние и внутренние угрозы финансовой безопасности предприятия. Финансы и кредит. 2009. № 16. C. 68-75. 14. Hutsaliuk, O., Koval, V., Tsimoshynska, O., Koval, M., Skyba, H. Risk Management of Forming Enterprises Integration Corporate Strategy. TEM Journal. 2020. № 9. C. 1514-1523. URL: https://doi.org/10.18421/TEM94-26 (дата звернення: 08.12.2020). 15. Tamosiuniene, R., Demianchuk, M., Koval, V. State Regulation of Bankruptcy Relations in the National Economy. Economics. Ecology. Socium. 2019. № 3. С. 19-27. 16. Толстошеєва А. В. Забезпечення безпеки кредитної діяльності банків : дис. ... канд. екон. наук : 08.00.08. К., 2015. 305 с. 17. Звіт про фінансову стабільність. Грудень 2020. Офіційна інтернет-сторінка Національного банку України. URL: https://bank.gov.ua/admin_uploads/article/FSR_2020-H2.pdf?v=4 (дата звернення: 08.12.2020).

\section{REFERENCES:}

1. Ekonomichna bezpeka / za red. 0. M. Dzhuzhi. K. : Alerta, 2010. $368 \mathrm{~s}$. 2. Baranovskyi O. Bezpeka bankivskoi sfery. Visnyk NBU. 2014. № 6. S. 20-27. 3. Yepifanov A. O. Finansova bezpeka pidpryiemstv i bankivskykh ustanov: monohrafiia. Sumy : DVNZ «UABS NBU», 2009. 295 s. 4. Vovchenko R. S. Finansova 
Серія «Економічні науки»

Випуск 4(92) 2020 p.

bezpeka bankivskoho sektoru ekonomiky Ukrainy : dys. ... kand. ekon. nauk : 08.00.08. K., 2016. 237 s. 5. Hubarieva I. O. Zabezpechennia upravlinnia ekonomichnoiu bezpekoiu banku : monohrafiia. Kharkiv : Inzhek, 2013. 309 s. 6. Zachosova N. V. Formuvannia systemy ekonomichnoi bezpeky finansovykh ustanov : monohrafiia. Cherkasy : PP Chabanenko Yu. A, 2016. 375 s. 7. Baryliuk M.-M. R. Analiz chynnykiv vplyvu na protses zabezpechennia finansovoi bezpeky komertsiinoho banku. Finansovyi prostir. 2017. № 1. S. 8-17. 8. Lisniak A. Ye. Evoliutsiia i klasyfikatsii pokaznykiv otsiniuvannia finansovoi bezpeky bankiv. Finansovyi prostir. 2018. № 3. S. 60-68. 9. Shevtsiv L. Yu. Shliakhy pidvyshchennia finansovoi bezpeky bankiv Ukrainy v umovakh hlobalizatsii nykh protsesiv. Biznes-inform. 2020. № 9. S. 254-262. 10. Baranovskyi A. Integral assessment of the financial security of commercial banks. Scientific Light. 2017. № 7. R. 34-45. 11. Prystupa L. Conceptual framework of financial security management of domestic banks in the current economic conditions. Suchasni vyklyky staloho rozvytku biznesu : materialy Mizhnarodnoi naukovoi konferentsii (5-6 lystopada 2020 r., m. Zhytomyr). Zhytomyr : DUZhP, 2020. S. 167-171. 12. Prystupa L. Assessment of banks financial security levels based on a comprehensive index using information technology. Machine Learning for Prediction of Emergent Economy Dynamics. 2020. Vol. 2713. Pp. 23. 13. Perekrestova L. V. Vneshnie i vnutrennie ugrozyi finansovoy bezopasnosti predpriyatiya. Finansyi i kredit. 2009. № 16. S. 68-75. 14. Hutsaliuk, O., Koval, V., Tsimoshynska, O., Koval, M., Skyba, H. Risk Management of Forming Enterprises Integration Corporate Strategy. TEM Journal. 2020. № 9. S. 15141523. URL: https://doi.org/10.18421/TEM94-26 (data zvernennia: 08.12.2020). 15. Tamosiuniene, R., Demianchuk, M., Koval, V. State Regulation of Bankruptcy Relations in the National Economy. Economics. Ecology. Socium. 2019. № 3. S. 19-27. 16. Tolstosheieva A. V. Zabezpechennia bezpeky kredytnoi diialnosti bankiv : dys. ... kand. ekon. nauk : 08.00.08. K., 2015. 305 s. 17. Zvit pro finansovu stabilnist. Hruden 2020. Ofitsiina internet-storinka Natsionalnoho banku Ukrainy. URL: https://bank.gov.ua/admin_uploads/article/FSR_2020-H2.pdf?v=4 (data zvernennia: 08.12.2020).

Prystupa L. A. [1; ORCID ID: 0000-0002-5088-0654], Candidate of Economics (Ph.D.), Koval V. V. [2; ORCID ID: 0000-0003-2562-4373], Doctor of Economics, Professor, Kovalenko-Marchenkova Ye. V. [3; ORCID ID: 0000-0001-7350-7740], Candidate of Economics (Ph.D.)

\author{
${ }^{1}$ Khmelnytskyi National University, Khmelnytskyi \\ ${ }^{2}$ Odessa Institute of Trade and Economics, Kyiv National University of Trade and \\ Economics, Odessa \\ ${ }^{3}$ Dnipropetrovsk State University of Internal Affairs, Dnipro
}

\title{
MANAGEMENT OF THE DEVELOPMENT OF THE NATIONAL BANKING SECTOR ON THE BASIS OF ENSURING THE FINANCIAL SECURITY OF BANKING INSTITUTIONS
}

The article reveals the modern understanding of the essence of the concept of "financial security of a bank" on the basis of an analytical study of existing approaches to the interpretation of the content of the financial security of an enterprise and the interpretation of the category of financial security of a bank. The main goal of the financial security of the bank as a 
separate banking institution and the banking sector as a whole in the financial services market has been determined. Attention is focused on the causal relationship of the occurrence and development of risk, danger and threat, determines the need for a system for creating a security system for a banking institution, which is a set of objects, subjects, principles, functions, assessment methods and a mechanism for strengthening bank security. The conditions for development, current phenomena and factors that can cause internal threats to the national banking sector as a whole and its institutions are indicated. In general, threat recognition and risk assessment to ensure sustainable development and a high level of financial security of a banking institution is achieved through the implementation of functions, the use of methods, tools, and managerial impact on correctly defined objects and goals. The banking system as a whole, and each bank in particular, needs to create a security system that can withstand threats, maintain liquidity and solvency, develop tools for early detection and prevention of threats, and also eliminate negative consequences. The tools for counteracting the consequences of crisis in the banking sector are disclosed, effectively applied at the level of the regulator, and, based on an analytical assessment of the state and trends of risks in the banking sector for the period banking institutions.

Keywords: banking sector; bank; financial security; management; threats; risks.

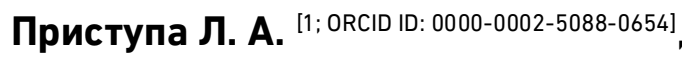
К.Э.H., Коваль В. В., [2; ORCID ID: 0000-0003-2562-4373], д.э.н., профессор, Коваленко-Марченкова Е. В. [3; ORCID ID: 0000-0001-7350-7740], к.э.н., доцент

\footnotetext{
${ }^{1}$ Хмельницкий национальный университет, Хмельницкий, Украина

${ }^{2}$ Одесский торгово-экономический институт Киевского национального торговоэкономического университета, Одесса, Украина

${ }^{3}$ Днипропетровский государственный университет внутренних дел, Днепр, Украина
}

\section{УПРАВЛЕНИЕ РАЗВИТИЕМ НАЦИОНАЛЬНОГО БАНКОВСКОГО СЕКТОРА НА ОСНОВЕ ОБЕСПЕЧЕНИЯ ФИНАНСОВОЙ БЕЗОПАСНОСТИ БАНКОВСКИХ УЧРЕЖДЕНИЙ}

В статье раскрыто современное понимание сущности понятия
«финансовая безопасность банка» на основе аналитического
исследования существующих подходов к трактовке содержания
финансовая безопасность предприятия и трактовки категории
финансовой безопасности банка. Определена основная цель финансовой
безопасности банка как отдельного банковского учреждения, так и


Серія «Економічні науки»

Випуск 4(92) 2020 p.

банковского сектора в целом на рынке финансовых услуг. Акцентировано внимание на причинно-следственной связи возникновения и развития риска, опасности и угрозы, определяет потребность системы создания обеспечения безопасности банковского учреждения, представляющая собой совокупность объектов, субъектов, принципов, функций, методов оценки и механизма укрепления безопасности банка. Указаны условия развития, актуальные явления и факторы, которые могут вызвать внутренние и внешние угрозы банковскому сектору национальной экономики в целом и его учреждениям. В целом распознавание угроз и оценка рисков для обеспечения устойчивого развития и высокого уровня финансовой безопасности банковского учреждения достигается за счет реализации функций, применения методов, инструментов, управленческого воздействия на правильно определенные объекты и цели. Банковской системе в целом и каждому банку в частности необходимо создать систему безопасности, которая сможет противостоять угрозам, поддерживать ликвидность и платежеспособность, разрабатывать инструменты для раннего обнаружения и предотвращения угро3, а также устранять негативные последствия. В статье раскрыты инструменты противодействия последствиям кризиса В банковском секторе, эффективно применены на уровне регулятора, и, на основе аналитического оценивания состояния и тенденций рисков банковского сектора за период 2015-2020 годов, предложенная этапная последовательность процесса риск-менеджмента и выделены приоритетные составляющие повышения уровня финансовой безопасности отечественных банковских учреждений.

Ключевые слова: банковский сектор; банк; финансовая безопасность; управления; угрозы; риски. 